\title{
The Development and Application of Positive Psychological Intervention Program for a College Ice Hockey Team
}

\author{
Jane Rhee ${ }^{1}$, Sang-Hyun Kwon ${ }^{1 *}$, Dong-Won Yook ${ }^{1}$ and Jung-Taek Shin ${ }^{2}$ \\ ${ }^{1}$ Yonsei University \\ ${ }^{2}$ Dong-Eui University
}

\section{Article Info}

Received 2021.09.15.

Revised 2021.12.08.

Accepted 2021.12.12.

Correspondence*

Sang-Hyun Kwon

kno1900@gmail.com

\section{Key Words}

Positive psychological Intervention program,

College ice hockey team,

Happiness,

Strength knowledge,

Team interaction

본 논문은 석사 학위 논문을

요약, 수정하여 작성.
PURPOSE This study aimed to develop a positive psychological intervention program for a college ice hockey team and test its effects based on application to the team. METHODS The demands of 78 college ice hockey players were asked through open questionnaires. Collected results underwent integrated analysis to develop the desired program through the participants who were also observers of the team. The objectives of the program were established, and an appropriate program was developed based on the analyzed data, expert opinion, and precedent research. The developed program was applied to 26 players of a college ice hockey team to verify its effects. Tasks included writing experience reports and in-depth interviews. The Happiness Measures 1, Strength Knowledge, and Team Interaction Questionnaires were also administered. Collected qualitative data were categorized to follow inductive analysis procedures, while paired $t$-tests were performed for quantitative data using SPSS 25.0. RESULTS To improve the application of the program in real situations and maintain credibility and validity, the program was developed based on analyses of individual and team demands, methods of the participant as an observer, expert opinion, and other considerations. Statistically meaningful differences in positive psychological mind, happiness, recognition and utilization of strengths, team interactions, team cohesion, and so on were found using paired t-tests comparing data before and after the developed positive psychological intervention program. CONCLUSIONS Providing opportunities to recognize individual and team strengths and have valuable experiences for each player could enhance interactions between teammates and create a favorable team environment.

\section{서론}

역대 올림픽 개인 최대 금메달 소유자 미국 수영 선수 Michael Phelps 는 2018년 미국 시카고에서 열린 '케네디 정신건강 포럼(The Kennedy Forum)'에서 자신이 우울증을 겪었다고 밝혔다. 적극적인 노력과 도 움을 받으며 극복했지만 특히 2012 런던 올림픽 이후 더 이상 수영 을 하고 싶지 않았을 만큼 행복하지 않았다고 말했다(Scutti, 2018). Professional Footballers' Association(PFA)에서는 2016년에만 현역 축구 선수 62 명과 전직 선수 98 명이 우울증에 대한 상담 요청을 했다고 밝혔고, 스코틀랜드 프리미어리그 하이버니안 FC 감독이자 선수 출신

(cc) This is an open-access article distributed under the terms of the Creative Commons Attribution Non-Commercial License (http://creativecommons.org/ licenses/by-nc/4.0/), which permits unrestricted non-commercial use, distribution, and reproduction in any medium, provided the original work is properly cited.
인 Neil Lennon은 “우리는 대중 앞에 용감한 척 나서야 하며 건강한 멘 탈을 유지하기 어려운 직업”이라고 말했다(Seo, 2017).

운동선수로서 금메달 획득과 프리미어리그 진출은 큰 성공과 기쁨 으로 여길 수 있다. 하지만 행복하지 않았다고 말하는 이들로부터 목표 성취가 무조건적인 행복을 보장하지 않고 때로는 심리적 어려움과 관 련할 가능성에 대해서도 유추해볼 수 있다. 선수들은 최고가 되기 위 해 노력하는 과정에서 반드시 잘 해야 한다는 부담감과 타인과의 끊임 없는 비교로부터 사회적 불안을 야기하는 등(Jeong \& Kim, 2014) 여 러 심적 문제를 겪기도 한다. 이와 같은 스트레스로부터 안정감을 찾 고, 최고 수행(peak performace)을 위해 심리기술훈련(Psychological Skills Training; PST)을 수행한다(Cheon \& Kim, 2019).

불안과 긴장을 이겨내고 수행 향상을 위한 정신적, 정서 트레이닝 인 심리기술훈련(Choi \& Song, 2017)의 목표와 시각은 기존 심리 학 학문적 입장과 유사하다. 심리학 분야는 제2차 세계대전부터 질병 
학적 모델에 근거하여 부정적 요인을 사전에 차단하는 것이 핵심적 인 관점으로 작용하였다(Nam, 2017). 하지만 미국 심리학자 Martin Seligman이 20세기 말 미국심리학회(American Psychological Association; APA) 연례 보고에서 그동안 부적응이나 약점에만 치중 하고, 인간 본연이 가진 긍정적 측면을 간과했던 전통 학문에 대해 성 찰의 필요성을 제창하는 연설(Compton \& Hoffman, 2019)을 시작 으로 21세기 초반부터 ‘긍정심리학'이 새롭게 대두되었다.

긍정심리학(positive psychology)이란 병리적 결핍보다 개인, 그 룹 또는 기관의 최적화된 기능(the optimal functioning), 플로리시 (flourishing), 강점(strength)에 초점을 두는 연구로 전환하려는 새로 운 패러다임이자 움직임 그 자체이다(Hendriks et al., 2020). 즉, 문 제점이 보이는 내담자 중심으로 이루어지던 학문 제한점을 보완하고 행복(happiness), 웰빙(well-being), 강점 추구를 강조하는 응용심리 학이다.

이러한 개념을 바탕으로 긍정적 정서, 인식, 행동 향상을 목표 로 하는 체계화된 훈련이 긍정 심리 개입(Positive Psychological Interventions; PPIs)이다(Chakhssi et al., 2018). 긍정 심리 개입 은 개인이 가진 강점에 대해 재확인하면서 발전시키고, 행복을 적 극적으로 추구하도록 돕는다(White \& Waters, 2015). 개입 활동 은 평소 쉽게 실천 가능하고, 긍정적 감정을 느끼며 의미 탐색이 가 능한 특징을 가진다. 또한 개인의 생각과 행동에 긍정적인 변화를 이 끌 수 있다. 특히 행복은 자신의 의지와 노력에 의해 만들 수 있고, 타 인과 상호작용을 통해 가치가 더해져 긍정적 정서가 부정적 정서 흐 름으로부터 보다 강해지는 기능을 한다(Seligman, 2002). 때문에 감 사하기(expressing gratitude), 개인 강점 활용하기(using personal strengths), 목표 설정(setting goals)과 같은 주요 활동들이 행복과 주관적 웰빙(subjective well-being)을 증가시키고, 우울감을 감소시 키는 효과가 있다고 밝혔다(Bolier et al., 2013).

긍정 심리 개입과 관련한 선행연구 초기 주요 연구 대상은 정서 조 절 장애 입원 환자 또는 우울증 척도 검사를 통해 판별된 우울 정도가 높은 대상(Guo et al., 2017), 환자(Louro et al., 2015)가 대표적이 다. 하지만 점차 연구 스펙트럼(spectrum)에 변화가 생기고 있다. 상 대적으로 스트레스와 우울감이 높은 상황에 놓여 있던 대상에서 군인 (Dolphin et al., 2015), 중년층(Ho et al., 2014), 일반 학생(Antoine et al., 2018)까지 확장하는 추세이다.

긍정 심리 개입 연구 대상이 다양해지는 만큼 여러 학자들에 의해 스포츠 현장에서 긍정심리학 활용 가능성을 고무적으로 바라보고 있 다. Matthews(2017)는 미국 육군의 정신 건강과 군 생활 적응을 위 해 긍정심리학을 반영하여 개발한 교육 프로그램 '종합 군인 피트니 스(Comprehensive Soldier Fitness; CSF)'를 살펴보면 군대라서 주 어지는 특수한 도전과제와 동일한 목표를 달성해야 하는 구조적 특 성은 스포츠 조직과 상당한 유사성을 가진다고 분석했다. Mann과 $\operatorname{Narula(2017)ㄴㅡㄴ~ㄱㅡㅇㅈㅓㅇㅅㅣㅁㄹㅣㅎㅏㄱㅇㅡㄹ~ㅅㅓㄴㅅㅜㅇㅔㄱㅔ~ㅈㅓㄱㅇㅛㅇㅎㅏㅁㅕㄴ~ㅁㅗㄱㅍㅛ~ㄷㅏㄹㅅㅓㅇ,~ㄷㅗㅇㄱㅣ~ㅅㅜ~}$ 준을 증진시킬 수 있어 정신적 강인함(mental toughness), 그릿(grit), 탄력성(resiliency) 등 긍정적 심리구조를 발전시키는 플랫폼이 될 수 있다고 강조하였다. Tamminen 등(2016)은 긍정적 감정 강화와 확대 는 선수의 행복감과 신체적, 사회적, 심리적 자원 형성과 발전을 촉진 하여 선수 경기력에 긍정적 영향을 줄 수 있다고 보고하였다.

긍정심리학 개념과 원리를 운동선수에게 적용한 선행연구는 대 학 야구 선수를 위한 긍정 심리 개입 단일 사례 연구(Park \& Shin, 2017), 야구, 배드민턴, 펜싱 대학 선수 대상 긍정 심리 개입 프로그
램 개발과 적용을 통해 정서, 자아존중감, 행복감 효과를 규명한 연구 (Lee \& Shin, 2017), 우수, 비우수 양궁 선수 강점 인식과 실제 경기 에서의 강점 활용을 분석한 연구(Park et al., 2018), 감사하기 개입으 로 운동선수에 대한 긍정심리학 활용 가능성 연구(Gabana, 2019)가 대표적이다. 이처럼 운동선수에게 긍정심리학 개념을 적용하여 선수 들의 긍정적 감정을 강화하고 행복감, 웰빙, 정신건강 증진을 위한 연 구 움직임이 일어나고 있다.

다양한 연구들을 통해 긍정심리학이 스포츠 현장에서 중요한 역할 을 할 수 있음을 시사하고 있으나 주로 개인 종목 선수 또는 개인 중심 활동 연구를 진행하여 스포츠 팀 대상 연구는 매우 미비한 실정이다. 스포츠에서 팀은 역동성을 가지고, 개개인이 모여 하나의 조직을 구 성한다. 공동의 목표를 이루기 위해 각자 맡은 책임을 다하면서 얼마 나 협력적으로 팀을 이끌어 가느냐에 따라 팀 경기 성과, 경기력이 좌 우될 수 있다(Kim et al., 2019). 이처럼 서로 밀접하게 관련을 맺고 있는 팀 안에서 선수 중 누구라도 행복감이나 긍정 정서 수준이 현저 히 낮다고 가정한다면 개인의 역할을 밀도 있게 수행하지 못해 팀 전 체에 부정적 영향을 초래할 가능성도 있다.

Parkinson(1996)은 개인의 감정이 다른 구성원으로 전염될 수 있 고, 관련한 정서 표현이 집단 내 감정 수렴을 이끌어 낸다고 말했다. 또한 선수의 스포츠 행동을 적극적으로 유도할 수 있는 긍정적 동기 가 작용하지 못 하거나 이로 인해 팀 구축 조성이 견고하지 않으면 최 대의 노력을 발휘하기 어려워 경기력에도 영향을 줄 수 있다(Moon \& Hong, 2011). 따라서 선수들에게 긍정 정서를 느낄 수 있는 활동 및 경험은 긍정심리학에서 말하는 행복감과 웰빙을 높일 수 있어 훈련 또는 경기 속에서 활력소가 되고, 긍정적 팀 분위기로 이어질 수 있다 는 추론이 가능하다.

팀 스포츠 중에서도 아이스하키는 선수들이 계속해서 교체하는 빠른 경기 흐름을 가지는 구기 종목이다. 팀 동료가 많으면서도 소그룹 조로 운영되며 상호의존성이 높은 특징을 가지기 때문에(Chamberlain et al., 2019) 팀원과의 협력이 중요하다. 이러한 종목 특징은 긍정심리학 적용의 의의와 필요성을 가질 수 있다.

따라서 본 연구 목적은 긍정심리학이 개인 또는 현장 환경에 따라 변형이 가능하다는 개념(Seligman, 2011)과 연구 대상자 문화적 배 경에 의해서도 개입 결과가 달라질 수 있다는(Hendriks et al., 2020) 이론적 근거를 바탕으로 대학 아이스하키 팀을 위한 긍정 심리 개입 프로그램을 개발하고 적용하는 것이다. 이와 같은 과정은 스포츠 현 장에 긍정심리학이 가지는 가치와 의미를 제시하고, 팀 중심 긍정 심 리 개입 프로그램 개발 기초 정보를 제공할 수 있을 것이다. 또한 프 로그램을 통해 다양한 긍정적인 활동을 경험하면서 선수 개인 그리고 소속 팀의 발전과 더 나아가 팀 성과에도 이바지할 것으로 기대한다.

\section{연구방법}

\section{연구참여자}

본 연구 참여자는 프로그램 개발을 위한 연구 참여자, 프로그램 적용 연구 참여자로 나누어지며 모두 2019년 대한아이스하키 협회에 정식 으로 등록된 아이스하키 선수로 선정하였다.

긍정 심리 개입 프로그램 개발을 위해 국내 대학교 아이스하키 4 개 팀 선수 총 78 명이 개방형 질문지 작성에 참여하였고, 프로그램 적용 
및 효과 검증을 위해 A대학교 아이스하키 팀 선수 26명이 참여하였 다. 심층면담은 프로그램 현장 적용에 참여한 $\mathrm{A}$ 대학교 선수 중 자발 적 참여 의사를 밝힌 4 명을 대상으로 진행하였다.

\section{측정도구}

\section{1. 개방형 설문}

프로그램 개발에 앞서 현장의 요구를 확인하고자 전문가 회의를 거 쳐 구성한 개방형 질문지(Kim, 2010; Kim \& Lee, 2019)로 요구분석 을 실시하였다.

팀 생활 행복 구성 요인과 심리적 손상 구성 요인을 알아보기 위해 '팀 생활을 하면서 행복했던 경험 또는 상황에 대해 자세하게 적어주 세요.', '팀 생활을 하면서 속상하거나 마음의 상처를 받은 경험 또는 상황에 대해 자세하게 적어주세요.' 질문을 제시하였다. 이와 더불어 일반 삶 속에서 행복 구성 요인과 심리적 손상 구성 요인을 파악하기 위해 '팀 생활을 제외한 일반적인 삶에서 언제 행복한지, 그 경험과 상 황에 대해 자세하게 적어주세요.', '팀 생활을 제외한 일반적인 삶에서 언제 속상하거나 마음의 상처를 받았는지, 그 경험 또는 상황에 대해 자세하게 적어주세요.'로 구성하였다. 마지막으로 팀 행복 필요 구성 요인을 알아보기 위해 '우리 팀이 행복해지기 위해서 필요하다고 생 각하는 것을 모두 적어주세요.' 질문을 제공하였다.

\section{2. 참여관찰}

대학 아이스하키 팀 선수들이 평소 어떻게 생활하는지 알아보며 현 장에 적합한 프로그램 개발을 위해 개방형 설문지 작성 대상자인 모 든 팀의 훈련을 1 회 이상 관찰하였다. 특히 $\mathrm{A}$ 대학교 중심으로 훈련 및 경기 일정에 참여하여 관찰자로서 참여관찰을 실시하였다. 대학 운동 선수들은 팀원들과 훈련만 하는 것이 아니라 같이 학교생활, 단체 숙 소생활을 하며 많은 시간을 보낸다. 때문에 연구자 역시 팀 구성원들 과 함께 할 때 연구와 관련한 새로운 관찰 기회가 있을 수 있고, 추후 프로그램 진행을 위한 라포(rapport) 형성을 고려하여 팀 시즌 일정에 참여하였다.

\section{3. 심리검사지}

본 연구를 통해 개발한 긍정 심리 개입 프로그램의 효과 검증을 위 해서 행복 검사 I, 강점 인식, 팀 상호작용 검사지를 활용하였다. 프로 그램을 적용한 $\mathrm{A}$ 대학교 팀 대상으로 개인 심리적 요인 변화를 살펴 보기 위해 행복감, 강점 인식에 대해서 그리고 팀 요인 변화를 알아보 기 위해 팀 상호작용 검사를 시행하였다.

1) 행복 검사 I (Happiness Measures I)

본 연구에서 행복 자각 정도를 검사하기 위해 행복검사 I(Fordyce, 1972)을 $\mathrm{Yu}(1988)$ 가 번안한 것으로 활용하였다. 행복의 강도와 양을 양면으로 측정할 수 있다. Part 1은 행복감에 대한 11단계 단문항 척 도, part2는 평균적으로 하루 몇\%의 시간동안 행복, 불행, 행복도 불 행하다는 느낌도 없이(중립 또는 무감각) 지내는지 $100 \%$ 비율을 가지 고 나눌 수 있도록 구성되어 있다.

2) 강점 인식(Strengths Knowledge Questionnaire)

강점 인식 측정을 위해 Govindji와 Linley(2007)가 개발하고, Park 등(2018)의 연구에서 활용한 총 8개 문항, 5점 리커트 척도 검사지를
활용하였다. 자신의 강점을 알고 있는지, 강점을 알기 위해 많이 생각 해야 하는지 등 강점에 대한 전반적인 개인 인지도를 파악할 수 있는 내용으로 구성되었다. 본 연구의 내적 신뢰도 Croncach's $\alpha$ 는 .89로 나타났다.

3) 팀 상호작용(Team Interaction Questionnaire)

팀 상호작용 측정을 위해 Kang과 Yang(2017)이 개발한 검사지 를 Hwang과 Kwon(2019)이 재구성한 총 5요인 25문항, 5점 리커 트 척도 검사지를 활용하였다. 지도자와의 소통 그리고 동화, 동료선 수와의 헌신, 동화, 소통에 대한 검사지이다. 본 연구의 내적 신뢰도 Croncach's $\alpha$ 는 .78로 나타났다.

\section{4. 경험 보고서 및 심층면담}

프로그램 적용 효과를 분석하기 위해 연구 대상자가 생각하는 인 상 깊었던 경험을 알아보고자 하였다. 특히 개입 전후 감정, 생각, 행동 변화를 경험 보고서(Kwon et al., 2016; Kim \& Lee, 2019; $\mathrm{Kim}, 2010)$ 에 작성할 수 있도록 하였다. 또한 자발적 의사를 밝힌 4 명의 선수에 대해 심층면담을 실시하였다. 사전 동의를 구한 후 면 담 내용을 녹취하며 60 분으로 설정한 반구조화된 면담(unstructured interview)을 진행하였다.

\section{5. 프로그램 평가지}

프로그램에 대한 추가적인 인식과 평가 조사를 위해 마지막 회기 종결 후 프로그램 참여자 대상으로 평가지(Kwon et al., 2016; Kim, 2010)를 작성할 수 있도록 하였다. 건의하고 싶은 사항이나 활동이 있었는지 프로그램 개선과 보완을 위한 문항을 포함하였다.

\section{연구 절차}

본 연구 절차는 크게 긍정 심리 개입 프로그램 개발 단계와 프로그램 적용 및 효과 검증 단계로 구분할 수 있다(Fig 1).

긍정 심리 개입 프로그램 개발은 스포츠심리학 분야의 프로그램 개발 절차를 바탕으로 진행하였다. 팀 커뮤니케이션 프로그램(Kim \& Lee, 2019), 팀 구축 프로그램(Kim, 2010), 팀 의사소통 프로그램(Kwon et al., 2016) 등 팀 스포츠 관련 프로그램 개발 선행연구의 문헌고찰, 요구분석, 전문가 회의 등과 같은 단계를 참고하였다. 첫째, 긍정 심리 개입과 관련한 선행연구(Boiler et al., 2013; Chakhssi et al., 2018; Donaldson et al., 2019)를 분석하면서 대학 아이스하키 4팀 감독 및 주장에게 훈련 관찰과 개방형 질문지 작성에 대한 사전

\begin{tabular}{|c|c|c|}
\hline $\begin{array}{c}\text { The Development of } \\
\text { Program }\end{array}$ & & $\begin{array}{l}\text { The Application of } \\
\text { Program }\end{array}$ \\
\hline $\begin{array}{l}\text { Literature Review } \\
\text { Needs Analysis } \\
\text { Participant Observation } \\
\text { Experts' Meeting } \\
\text { Integrated Analysis } \\
\text { Goal Setting } \\
\text { Development of Activities }\end{array}$ & $\checkmark$ & $\begin{array}{l}\text { Pre-Tests } \\
\text { Program Implementation } \\
\text { Post-Tests } \\
\text { Experience Report } \\
\text { In-depth Interview } \\
\text { Evaluation Program }\end{array}$ \\
\hline
\end{tabular}

Fig 1. Process of the program development and application 
협조를 요청하였다. 이후 연구자가 직접 훈련 장소에 방문하여 연구 목적에 대해 설명하고 개방형 질문지를 배포하였다. 둘째, 프로그램을 적용한 $\mathrm{A}$ 대학교 팀 감독 동의하에 팀 일정에 참여하고, 관찰자로서 참여관찰을 통한 자료 수집을 하였다. 셋째, 요구분석 결과와 여러 자료들을 토대로 전문가 회의를 진행하였다. 넷째, 자료 통합 분석을 하면서 프로그램 목표, 단계, 세부 활동을 구성하며 최종 프로그램을 개발하였다.

프로그램 개발에 이어 적용 및 효과 검증 절차는 다음과 같다. 첫째, 본 연구를 통해 개발한 긍정 심리 개입 프로그램을 $\mathrm{A}$ 대학 아이스하키 팀 지도자에게 프로그램 목적, 활동 구성 내용에 대해 설명하고 시행 동의를 구하였다. 둘째, 프로그램 효과 검증을 위해 검사지(행복검사 I, 강점 인식, 팀 상호작용)에 대한 사전검사를 실시하였다. 셋째, 팀 일정을 고려하여 주 1회-2회, 학교 또는 훈련장에서 약 두 달 동안 프로그램을 진행하였다. 넷째, 프로그램 효과 검증을 위해 선수들에게 검사지 사후검사 시행 그리고 경험보고서와 프로그램 평가지 작성을 요청하였다. 마지막으로 프로그램에 참여했던 4 명의 선수를 대상으로 심층면담을 진행하였다.

\section{자료 분석}

긍정 심리 개입 프로그램 적용 효과를 알아보기 위해 프로그램 시행 전후로 수집한 검사지 데이터는 대응 표본 $t$ 검증법(Paired Samples t-test)을 활용하여 분석하였다. 통계적 자료는 SPSS(version. 25) 프로그램을 통해 분석하고, 유의수준은 $p<.05$ 로 설정하였다.

또한 프로그램 개발 및 적용 효과 분석을 위해 질적 도구를 활용한
수집 자료는 다음과 같이 정리하였다. 귀납적 범주 분석 절차에 따라 유사한 의미를 가지는 내용, 문장, 단어별 범주화 방법을 통해 코딩 영역(coding category) 분류를 하였다. 모든 자료는 전사(transcribe)하고, 주관적 해석을 최소화하기 위해 동료검증과 전문가 회의 삼각검증(investigator triangulation)을 하였다. 요구분석, 참여관찰, 문헌고찰 등 자료 수집을 지속적으로 병행하고, 다각도로 분석하여 신뢰도와 타당성을 확보하였다.

\section{연구결과}

\section{프로그램 개발}

팀을 위한 긍정 심리 개입 프로그램을 개발하기 위해 국내 대학 아이스 하키 선수 대상으로 요구분석과 참여관찰을 실시하였다. 프로그램 목표는 수집한 자료를 바탕으로 전문가 회의를 통해 설정하였다. 세부 활동은 선행연구의 대표적인 활동과 원리를 참고하여 개발 및 구성하였다. 프로그램을 적용하는 팀 시즌과 학교 일정, 훈련 장소를 고려하여 팀 관계자와 함께 회기 순서를 조정하는 과정까지 거쳐 최종 프로그램을 개발하였다.

\section{1. 요구분석}

프로그램 개발을 위해 개방형 질문지를 활용하여 국내 대학교 아이스하키 팀 선수 78 명 대상으로 요구분석을 실시하고, 구성 요인 분석을 하였다(Table 1).

Table 1. Results of needs analysis

\begin{tabular}{|c|c|c|}
\hline Components & Lower order themes & Higher order themes \\
\hline \multirow{5}{*}{$\begin{array}{l}\text { The components of } \\
\text { happiness in team life } \\
(n=106)\end{array}$} & Championship, Standing award & Winning the competition $(51.89 \%)$ \\
\hline & Harmony, Interaction & Time with team members $(29.25 \%)$ \\
\hline & Overcoming, Growth, Competency, Gratitude etc. & Strengths use $(11.32 \%)$ \\
\hline & Unity, Cohesion & Sense of belonging $(3.77 \%)$ \\
\hline & Refreshment & Psychological refreshment $(3.77 \%)$ \\
\hline \multirow{5}{*}{$\begin{array}{l}\text { The components of } \\
\text { psychological hurt in } \\
\text { team life } \\
(n=93)\end{array}$} & Manner, Trust, Respect, Consideration & Conflict and discord with team members $(45.16 \%)$ \\
\hline & Performance and mistake, Lose & Situation related to the match $(38.71 \%)$ \\
\hline & Internal factors, External factors & Psychological factors $(7.53 \%)$ \\
\hline & Team environment & Team operation and environment $(5.38 \%)$ \\
\hline & Injury & Injury $(3.23 \%)$ \\
\hline \multirow{4}{*}{$\begin{array}{l}\text { The components of } \\
\text { happiness in everyday } \\
\text { life }(n=126)\end{array}$} & Friends, Family, Couple & Relationship (48.41\%) \\
\hline & Hobbies and leisure activities, Rest, Foods & Vacation and free time $(40.48 \%)$ \\
\hline & Time for personal development and fulfillment & Self-development $(5.56 \%)$ \\
\hline & College festival & Campus life $(5.56 \%)$ \\
\hline \multirow{5}{*}{$\begin{array}{l}\text { The components of } \\
\text { psychological hurt in } \\
\text { everyday life } \\
(\mathrm{n}=66)\end{array}$} & Friends, Family, Couple & Relationship (40.91\%) \\
\hline & Internal factors, External factors & Psychological factors $(15.15 \%)$ \\
\hline & Career preparation & Career $(12.12 \%)$ \\
\hline & Assignment, Examination, Grade & Studying $(6.06 \%)$ \\
\hline & Prejudice for sports teams, Lack of privacy etc. & Prejudice for sports teams, Privacy etc. $(19.70 \%)$ \\
\hline \multirow{4}{*}{$\begin{array}{l}\text { The components for } \\
\text { team happiness } \\
(\mathrm{n}=121)\end{array}$} & Unity, Atmosphere, Specific goals, Clarity of role etc. & Team factors $(40.50 \%)$ \\
\hline & Considerate and respectful & Respect \& Consideration $(22.31 \%)$ \\
\hline & Blaming, Communication, Trust and understanding & Trust and expressing emotions $(22.31 \%)$ \\
\hline & Team environment, Winning, Positive mind. & Team environment, Win, Positive mind. (14.88\%) \\
\hline
\end{tabular}


그 결과 팀 생활을 하면서 행복했던 경험과 상황은 '대회 우승'이 가장 높은 비중을 차지하였고, 다음으로는 팀원과의 시간이나 화합하는 '상호작용', 팀 경기력 향상과 개인 및 팀 목표 달성에 기여하는 '강점 활용', 단합되고 소속감을 느끼는 '결속력', 해외 전지훈련을 통해서 느끼는 '심리적 환기' 순으로 나타났다. 이는 프로그램 구성 시 개인 강점에 대해 다루고, 팀원과의 교류 기회 제공에 대해 고려해야 할 필요성을 알 수 있다. 또한 팀 생활을 하면서 속상하거나 마음의 상처를 받았던 경험과 상황에 대한 질문을 통해 '팀 생활 심리적 손상 구성 요인'도 탐색하였다. 팀원이 짜증을 내거나 배려가 없을 때 발생하는 '팀원과의 갈등 및 불화', 실책하거나 크게 패하는 '경기상황', 심리적으로 위축되어 어려움을 느끼는 '심리적 요인', '팀 운영 및 환경', '부상' 순으로 나타났다.

앞서 나온 결과에서 알 수 있듯이 팀 생활 시 행복을 느끼는 구성 요인 중 '대회 우승'은 선수들에게 큰 의미를 가지는 것으로 나타났지만 오히려 팀 생활 시 심리적 손상은 승패보다 팀원의 언행이나 신뢰 문제, 존중과 배려가 없을 때 많이 느낀다는 점을 주목할 필요가 있다. 따라서 팀원과의 긍정적 감정 및 경험 공유를 통한 상호작용 증진이 요구된다는 분석이 가능하다.

팀 생활과 더불어 일상생활 속 행복 구성 요인과 심리적 손상 요인에 대해서도 알아본 결과 일반 삶 속에서의 행복 구성 요인은 친구 또는 가족과 함께 하는 '인간관계', 휴가나 취미활동을 하는 '휴식 및 다양한 활동', 개인 발전에 도움이 되는 '자기 계발', 학교 행사나 축제에 참여하여 즐기는 '학교생활' 순으로 나타났다. 그리고 일반 삶 속에서 느끼는 심리적 손상 구성 요인은 가족, 친구 등 갈등이 발생하는 '인간관계', 열등감을 느끼는 '심리적 요인', 미래에 대한 고민이 많아지는 '진로', 노력을 했음에도 불구하고 기대 이하 성적이 나오기도 하는 '학업', 운동선수에 대한 선입견을 느꼈을 때 '운동부 편견' 등 내용 순으로 나타났다.

이 결과에서도 역시 선수들은 대인 관계 속에서 행복감, 심리적 손상감을 느끼기 때문에 팀원, 가족과의 긍정적인 관계 유지와 발전에 대한 중요성을 설명해준다.

마지막으로 자신이 속한 팀이 행복해지기 위해서 무엇이 필요한지 ‘팀 행복 필요 구성 요인'을 탐색하였다. 화목한 분위기 속에서 한마음으로 명료한 역할을 수행하는 '팀 요인', '존중 및 배려', 서로 짜증내지 않고 믿으며 고마움을 표현하는 '신뢰 및 감정 표현', 학교의 지원을 통한 '팀 환경' 조성, '대회 우승', 작은 것에도 감사하고 행복을 느낄 줄 아는 ‘긍정 심리’ 순으로 나타났다.

팀 생활의 행복을 구성할 수 있는 대표적 요인은 함께 단합하여 서로 배려하는 것이 가장 필요하다고 한 내용으로부터 긍정 심리 기반 팀 프로그램 개발 방향성을 참고할 수 있다.

\section{2. 통합 분석 및 프로그램 목표 설정}

본 연구 목적은 팀을 위한 긍정 심리 개입 프로그램을 개발하고 적용하여 선수들의 강점 인식 개념 확립과 재발견 기회를 제공하는 것이다. 이와 함께 팀 상호작용을 활발하게 하여 긍정적인 팀 분위기 조성을 토대로 행복감을 증진시키고자 하였다. 이러한 연구 목적을 바탕으로 스포츠심리학 교수 2 명과 스포츠심리학 전공 박사 1 명으로 구성한 전문가 회의를 실시하여 개방형 질문지와 참여관찰 내용을 토대로 통합적인 분석을 하고, 프로그램 목표를 수립하였다.

개방형 질문지에서 자세한 분석을 위해 팀 생활과 일반 생활로 구분하여 질문을 제시하였다. 하지만 운동선수의 삶을 이분법적으로
확연하게 구분하기 어렵다. 선수들의 감정과 스트레스 대처에 따라 성과 만족감에도 영향을 주기 때문이다(Nicholls et al., 2012). 결국 일상생활에서 느끼는 행복감과 심리적 손상감은 운동 상황 중에 영향을 미칠 수 있고, 이와 반대로 작용할 수도 있다. 따라서 프로그램 활동 조직 시 팀과 관련한 구성 요인들은 주요 활동으로 반영하고, 개인 실천과제를 통해 일상에도 연결해보는 강화 효과를 고려하였다.

구체적인 구성 요인 탐색 결과 선수들은 팀 행복을 위해 단합을 필요로 하며 해외전지훈련을 통한 경험을 할 때 행복감을 느낀다고 답하였다. 또한 개인 강점을 발휘하여 자신의 유능성을 확인하고, 노력을 통해 팀에 기여했을 때 성취감과 행복한 감정을 느낀다고 하였다. 프로그램 목적과 부합하는 이와 같은 구성 요인들은 프로그램 개발을 위한 주요 변인으로 고려하였다. 대회 우승 또는 패배, 사생활 등과 같은 구성 요인은 프로그램 요소로 활용하기에 외부적 요인이 많이 작용할 수 있어 부적합하다고 판단하여 제외하였다.

또한 참여관찰을 통해 선수들을 살펴본 결과 유사한 생활 패턴을 가지며 제스처(gesture)를 활용한 의사소통 모습을 자주 관찰하였다. 단합을 추구하며 하나처럼 보여도 선후배, 학과 등 부분적인 소그룹을 형성한다는 특징과 공통의 관심사가 있으면서 각자 개성이 뚜렷하다는 점을 발견할 수 있었다.

요구분석, 참여관찰 등 여러 측면에서 수집한 자료를 바탕으로 전문가 회의를 통해 설정한 프로그램 방향성과 목표는 다음과 같다. 첫째, 개인 강점 인식 기회를 제공한다. 둘째, 긍정 정서 및 심리적 환기를 경험할 수 있는 다양한 활동과 실천과제를 구성한다. 셋째, 팀 상호작용과 결속력에 도움이 될 수 있는 팀 활동을 포함한다. 마지막으로 긍정적인 팀 분위기 조성과 행복감 증진을 추구하자는 주요 목표를 설정하였다.

\section{3. 프로그램 활동 개발 및 단계}

프로그램 개발 단계에서는 다양한 자료 수집 내용과 전문가 회의에 따른 통합 분석으로 프로그램 전체 회기 수, 세부 활동들을 구성하였다. 긍정 심리 개입에 대한 메타분석 선행연구(Bolier et al,, 2013; Chakhssi, et al., 2018; Hendriks et al., 2020)에서 언급한 면대면(face-to-face) 방식과 평균 8-10회기(duration of the interventions) 효과성 결과에 의거하여 10회기 면대면 팀 상담 프로그램으로 설정하고, 지속적인 개발, 수정, 보완, 추가 과정을 거쳐 최종 프로그램을 개발하였다(Table 2).

기존 긍정 심리 개입 연구들은 주로 개인 활동 중심으로 이루어졌지만 본 연구는 '팀'에 초점을 두고 개발하였다. 물론 개인에 대해서도 살펴보는 내용을 포함하였다. 팀원들이 활발한 교류를 할 수 있는 방법과 소외감을 느끼는 구성원이 발생하지 않도록 여러 상황을 고려하였다. 프로그램에서 다루는 주제가 민감성을 가지는지, 이로 인해 팀원 사이에서 나타날 수 있는 부작용에 대해서도 검토하였다. 선수들은 팀이라는 집단에 긴밀하게 묶여 있고, 팀이 인생에 있어 삶의 중요한 영역으로 작용하는 특수성(Scholes, 2017)을 항상 유의하였다.

본 연구의 프로그램은 긍정심리학 기반이라는 점, 팀을 대상으로 하는 특징, 상호작용을 위해 팀 구성원 의사소통이 필수적인 사항을 고려하여 관련할 수 있는 선행연구(Kwon et al., 2016; Kim, 2010; Kim \& Lee, 2019; Lee \& Shin, 2017; Seligman et al., 2005)를 개발 목적에 맞게 참고하였다. 추가로 프로그램의 원활한 운영과 세부 활동 진행을 위해 선수들이 활용할 수 있는 활동지도 구성 및 개발하였다. 
또한 프로그램 체계성과 타당성을 위해 조직 구성원의 긍정적인 정서, 사고, 행동 이점을 연구하는 긍정심리학 조직적 접근 방법 " $4 \mathrm{D}$ Process'를 토대로 프로그램 단계를 재구성하였다. 4D Process(cycle)란 개인과 조직 강점을 강조하며 미래를 낙관적으로 사고하는 대화 기반 프레임이다. 강점과 가치 발견, 잠재력과 긍정적 요인 탐구, 긍정적 발전을 위한 일상 변화를 실천하는 절차 및 단계(발견하기, 꿈꾸기, 디자인하기, 실현하기)를 포함한다(Oades et al., 2017; Van Zyl et al., 2016).

\section{4. 최종프로그램 개발}

1 회기는 팀 구성원들에게 프로그램 진행자로서 연구자 정식 소개와 함께 활동 목적, 필요성을 전달한다. 적극적 참여와 동기 부여를 위해 프로그램 참여 동의서를 작성하고 검사지를 통한 사전검사를 시행한다.

2 회기는 우선 자신의 하키 플레이 강점, 성격적 강점을 스스로
찾아보는 활동으로 시작한다. 이후 제비뽑기 방법을 통해 무작위로 선정된 자신의 팀원 강점 찾기 활동을 한다. 강점을 언급하는 것만으로도 도움이 된다는 사례(Gelso et al., 2014)를 참고하여 개인 강점과 팀원 강점 찾기 활동을 통한 상호작용 증진 목적을 가진다. 이 과정으로 자신이 미처 생각하지 못한 강점을 재발견할 수 있고, 팀원이 동일한 내용을 말할 때 강화 효과를 기대하였다. 강점은 조직 현장의 문제를 해결해주고, 다른 사람과 구별해주는 매개체가 되며(Lopez et al., 2018) 대인 관계를 통해서도 개발할 수 있기 때문에 이와 같은 회기를 구성하였다.

3 회기는 팀 강점을 찾는 시간이다. 강점 인식은 상호 간의 이해를 통한 관계 향상 이점을 가진다(Lopez et al., 2018). 긍정적인 팀 분위기를 형성하고, 팀에 대한 소속감을 가지도록 기대하는 회기이다. 팀 강점 찾기 활동만으로 끝내지 않고, 참여관찰을 통해 선수들이 제스처를 활용하면서 소통했던 모습을 참고하여 팀 강점을 상징화하는

Table 2. The positive psychological intervention program for a college Ice hockey team

\begin{tabular}{|c|c|c|c|c|c|}
\hline Stage & \multicolumn{2}{|c|}{ Session \& Title } & Theme & \multicolumn{2}{|c|}{ Activities \& Reference } \\
\hline \multirow{5}{*}{ Discovery } & 1 & Starting & Orientation & \multicolumn{2}{|c|}{ Explanation of the program and execution of pre-tests } \\
\hline & \multirow[b]{2}{*}{2} & \multirow[b]{2}{*}{ Rediscovery } & \multirow{2}{*}{$\begin{array}{l}\text { Discovery of } \\
\text { strengths }\end{array}$} & \multicolumn{2}{|c|}{ Discovery of self and teammate's strengths in hockey play styles and characters } \\
\hline & & & & $\begin{array}{l}\text { Exercise } \\
\text { Reference }\end{array}$ & $\begin{array}{l}\text { Interview with acquaintances to identify own strengths } \\
\text { Gelso et al., 2014; Lope } \mathrm{z} \text { et al., } 2018\end{array}$ \\
\hline & & \multirow[b]{2}{*}{ Reinforcing } & \multirow{2}{*}{$\begin{array}{l}\text { Discovery of } \\
\text { team strengths }\end{array}$} & \multicolumn{2}{|c|}{ Discovery of team strengths to create new team ceremonies } \\
\hline & 3 & & & $\begin{array}{l}\text { Exercise } \\
\text { Reference }\end{array}$ & $\begin{array}{l}\text { Review of match videos } \\
\text { Lopez et al., } 2018\end{array}$ \\
\hline \multirow{2}{*}{ Dream } & \multirow{2}{*}{4} & \multirow{2}{*}{ Advancement } & \multirow{2}{*}{ Forgiveness } & \multicolumn{2}{|c|}{$\begin{array}{l}\text { Reflection of disappointing games and occasions in team or school lives, Imagining } \\
\text { a successful or better future }\end{array}$} \\
\hline & & & & $\begin{array}{l}\text { Exercise } \\
\text { Reference }\end{array}$ & $\begin{array}{l}\text { Remind of thankful occasions to team members } \\
\text { Cannon \& Edmondson, 2005; Weinzimmer \& Esken, } 2017\end{array}$ \\
\hline \multirow{8}{*}{ Discovery } & \multirow[b]{2}{*}{5} & \multirow[b]{2}{*}{ Expressing } & \multirow[b]{2}{*}{ Gratitude } & \multicolumn{2}{|c|}{ Collection of stories related to team successes, To write a letter to teammates } \\
\hline & & & & $\begin{array}{l}\text { Exercise } \\
\text { Reference }\end{array}$ & $\begin{array}{l}\text { Expression of gratitude to someone you appreciate, like writing a letter } \\
\text { Lee \& Shin, 2017; Meyers et al., } 2013\end{array}$ \\
\hline & \multirow[b]{2}{*}{6} & \multirow[b]{2}{*}{ Flow } & \multirow[b]{2}{*}{ Savoring } & \multicolumn{2}{|c|}{ Freestyle training including enjoyable mini games } \\
\hline & & & & $\begin{array}{l}\text { Exercise } \\
\text { Reference }\end{array}$ & $\begin{array}{l}\text { Recording of pleasant activities related to you for a weekend } \\
\text { Hefferon \& Boniwell, 2011; Kim \& Shin, } 2017\end{array}$ \\
\hline & \multirow{2}{*}{7} & \multirow{2}{*}{ Documentation } & \multirow{2}{*}{$\begin{array}{l}\text { Three good } \\
\text { things }\end{array}$} & \multicolumn{2}{|c|}{$\begin{array}{l}\text { Recording of experiences from three good things, Fulfillment of three pledges to be } \\
\text { achieved }\end{array}$} \\
\hline & & & & $\begin{array}{l}\text { Exercise } \\
\text { Reference }\end{array}$ & $\begin{array}{l}\text { Collection of photos; Sharing good memories with team members } \\
\text { Seligman et al., } 2005\end{array}$ \\
\hline & \multirow[b]{2}{*}{8} & \multirow[b]{2}{*}{ Remember } & \multirow[b]{2}{*}{ Sharing } & \multicolumn{2}{|c|}{ Dormitory of hallway boards by posting photos after sharing with team members } \\
\hline & & & & $\begin{array}{l}\text { Exercise } \\
\text { Reference }\end{array}$ & $\begin{array}{l}\text { Remind of thankful occasions to team members } \\
\text { Bryant \& Veroff, } 2007\end{array}$ \\
\hline \multirow[b]{2}{*}{ Design } & \multirow[b]{2}{*}{9} & \multirow[b]{2}{*}{ Achievement } & \multirow[b]{2}{*}{ Setting goals } & Establishme & t of individual and team goals \\
\hline & & & & $\begin{array}{l}\text { Exercise } \\
\text { Reference }\end{array}$ & $\begin{array}{l}\text { Implementation of own goals } \\
\text { Kwon et al., 2016; Liu et al., } 2012\end{array}$ \\
\hline Destiny & 10 & Promising & Closing & Completion & of program and execution of post-test \\
\hline
\end{tabular}

Other references: Boiler et al., 2013; Chakhssi et al., 2018; Donaldson et al., 2019; Kim, 2010, Kim \& Lee, 2019; Oades et al., 2017; Van Zyl et al., 2016 
팀 세레머니에 대해 토론하는 시간을 제공한다. 새로운 팀 세레머니를 상의하며 선수들이 심리적 환기를 느끼고, 미래에 대한 기대감을 조성하여 긍정적 정서 공유와 상호작용을 위한 활동이다.

4 회기는 긍정조직학 용서하기 원리를 팀에 초점을 맞춰 실수 개선 내용을 다루며 낙관성 원리로 연결하는 회기이다. 조직은 여러 구성원이 공존하고, 환경적 역동성이 존재하기 때문에 실수가 필연적이다(Cameron et al., 2003). 실수로부터 배움의 기회를 가질 수 있는 환경은 탐색적인 학습을 향상시키므로 실수를 인정하고 수용할 줄 알아야 한다(Weinzimmer \& Esken, 2017). 실수를 바라보는 태도에 따라 개인 정서에 영향을 줄 수 있다는 선행연구(Cannon \& Edmondson, 2005)에 의거하여 지금까지 경기 중 본인 플레이에서 아쉬웠던 점, 학업 등 학생 운동선수로서 성찰해본다. 그리고 앞으로 유사한 상황에서 어떻게 극복할 것인지 미래를 낙관적으로 그려보는 시간을 가진다.

5회기 '감사하기' 회기는 팀원과 긍정적 상호작용 및 감정 표현을 기대하는 활동이다. 세부 활동은 조직 성공담(Meyers et al., 2013)이자 가장 기억에 남는 경기를 회상하며 팀에 대한 소속감, 감사한 추억들을 다룬다. 다음으로 팀원에게 고마운 마음을 표현하는 편지 쓰기 시간을 가진다. 자신이 감사함을 표현하고 싶은 구성원에게 쓰는 것도 방법이 될 수 있지만 자칫하면 인기투표로 이어질 수 있어 교류가 적었던 팀원과의 관계 증진을 위해 무작위로 진행하였다. 대신 개인적으로 감사함을 표현하고 싶은 사람에게 편지를 써볼 수 있도록 실천과제를 제시하여(Lee \& Shin, 2017) 대상 선택 자율성을 부여한다. 요구분석에서 선수들이 가족, 친구로부터 행복감을 많이 느끼는 것을 알 수 있었기 때문에 실천과제는 지인에게도 속마음을 전해보면서 긍정 정서 강화 효과를 고려하였다.

6회기는 음미하기 활동이다. 음미하기의 원리는 긍정적인 경험으로부터 행복감을 증진시키는 방법론이며 타인과 공유하기 등 다양한 응용이 가능하다(Hefferon \& Boniwell, 2011). 선행 연구(Park \& Shin, 2017)에서는 새로운 것을 배우는 활동이나 여행하기 활동을 제시하였다. 하지만 본 연구는 팀 중심 프로그램이라는 점을 생각할 때 앞서 소개한 개인 활동만으로 대체하기에 부족하다고 판단하였다. 또한 참여관찰을 통해 반복적인 생활 패턴 모습을 확인 할 수 있었고, 심리적 환기를 원하는 요구분석 결과를 참고하여 선수들에게 일종의 자유 시간 제공 회기를 구성하였다. 재미있게 할 수 있는 훈련 방법이나 미니 게임 아이디어를 서로 제안하며 아이스하키 자체에 몰입하고 온전히 즐길 수 있게 기획한 회기이다. 또한 프로그램을 실제 훈련으로도 연결하여 링크장이라는 주요 생활공간에서도 프로그램 내용을 적용하는 목적을 가진다.

7회기는 긍정심리학 대표 학자 Martin Seligman이 제시한 방법으로 쉽게 실천 가능하고, 습관화가 되면 더욱 행복감을 높일 수 있는 TGT(Three Good Things) 방법을 활용하였다. 삶에서 좋은 것 또는 그날 좋았던 일 3 가지 등 사소한 것이라도 좋은 감정을 불러일으킨 일이나 대상을 생각하면 긍정 정서 강화 효과를 볼 수 있다고 밝혔다(Seligman et al., 2005). 동기 유발을 위해 먼저 자신이 좋아하는 것을 자유롭게 쓰게 하고, 이후 기존 활동과 유사하게 최근 긍정적으로 느꼈던 TGT를 찾도록 진행한다. 이후 연장선으로 '3가지 팀 공약 실천 활동'을 구성하였다. 서로 칭찬하기, 배려, 존중과 관련할 수 있는 실천 행동에 대한 3 가지 공약을 공유하는 회기이다. 팀에서 전술적 기여도 중요하지만 사소한 마음과 행동이 자신과 팀에게 긍정적으로 작용할 수 있다는 메시지를 전달하고자 하였다. 팀 역할에
대한 명확한 이해는 원활한 커뮤니케이션이 가능하여 개인 성취감과 잠재력을 이끌어 낼 수 있고, 선수 만족도와 팀 발전에 효과적일 수 있다(Choi \& Kim, 2011). 따라서 긍정 정서 확장 중요성을 다루고, 작은 행동에도 가치와 의미를 두는 회기이다.

8회기는 팀 상호작용을 위해 감사하기, 음미하기 원리를 반영하여 기획한 활동이다. 선행연구 음미하기 활동 중 경험을 나눌 수 있는 사람을 찾아 대화하기, 기념할 수 있는 물건을 통해 긍정적 정서를 다루는 방법이 있다(Bryant \& Veroff, 2007). 이를 참고하여 해당 회기 시행 전에 팀원과 같이 찍은 사진 중 가장 마음에 드는 것을 선택하여 제출하고, 연구자는 취합한 사진들을 인화한다. 팀 감독 협조를 통해 기숙사 복도 게시판에 선수들이 직접 선정한 사진들을 함께 부착한다. 사진을 보며 추억을 공유하고, 남은 시즌에 있어 결속력 다질 수 있는 기회 제공 목적을 가진다.

9회기는 개인 운동, 생활 목표와 팀 목표를 세우는 회기이다. 실천 가능한 행동과 생각을 정리하여 계획할 수 있는 시간이다. 특히 운동선수에게 구체적이고 도전적인 목표 설정(Liu et al., 2012)과 긍정적 자기 모니터링은 동기 부여로 작용할 수 있다. 팀 생활과 팀에 원동력이 될 수 있도록 개인과 팀 전체 내용을 함께 다룬다. 목표 설정 시 프로그램을 통해 경험한 긍정 심리 관련 내용을 반영할 수 있도록 가장 후반부 활동으로 구성하였다(Kwon et al., 2016).

10 회기는 마지막 회기를 종결하며 팀을 위한 긍정 심리 개입 프로그램 의미와 내용을 전반적으로 복습한다. 프로그램 참여 소감을 공유하고 마무리 인사 후 검사지 사후검사를 시행한다. 또한 경험보고서와 프로그램 평가지 작성을 통해 다양한 각도에서 경험을 살펴보고, 프로그램 평가 내용을 수집하는 목적을 가진다.

\section{프로그램 적용 및 효과 검증}

\section{1. 프로그램 적용}

본 연구에서 최종적으로 개발한 긍정 심리 개입 프로그램은 10 월 초 11월 말까지 약 2개월 동안 주 1 회 또는 2회 시행하였다. 기본적으로 60 70분 구성하고, 아이스링크장에서 하는 경우 장비 착용 시간을 고려하여 90분으로 설정하였다. 회기별 활동은 팀 일정에 따라 전지 훈련장, 운동부 기숙사 세미나실, 링크장 등 상황에 맞게 진행하였다. 팀원은 총 27 명으로 1 명의 선수는 개인 사정상 전반적인 프로그램 참여가 어려웠지만 26명 전원이 참여하였다. 매 회기 시작 전 지난 실천과제 소감 발표를 하고, 선수 동기와 흥미를 위해 해당 회기 내용과 관련한 영상도 시청하였다. 개인, 팀별로 활동지를 작성하면서 지원자나 추천을 통해 서로 생각을 공유하는 시간을 제공하였다. 또한 주요 활동은 팀 상호작용에 초점을 두고, 실천과제는 지인, 가족 등 일반 삶 속에서도 적용하도록 구성하여 프로그램 진행 이후에도 경험한 내용을 활용할 수 있게 하였다. 매 회기 종료 후 전문가 회의를 통해 활동지 작성 내용, 팀 분위기, 발표 내용에 대해서도 검토하였다.

\section{2. 프로그램 효과 검증}

대학 아이스하키 팀을 위한 긍정 심리 개입 프로그램을 A대학교 아이스하키 팀에 적용하였다. 프로그램 적용 효과 검증을 위해 검사지(행복 검사 I, 강점인식, 팀 상호작용)를 활용하여 양적 자료 분석, 경험보고서 및 프로그램 평가지 작성 그리고 심층면담을 통해 질적 자료 분석을 실시하였다. 
1) 양적 분석: 검사지

본 연구를 통해 개발한 프로그램 적용 효과 검증을 위해 행복 검사 $\mathrm{I}$, 강점 인식, 팀 상호작용 검사지를 프로그램 적용 전후 측정하여 차이를 확인하였다(Table 3).

분석 결과 첫째, 긍정 심리 개입 프로그램이 아이스하키 선수들의 행복감에 미치는 효과를 사전, 사후에 측정한 평균 및 표준편차를 살펴보면 사전 $(M=5.35)$ 보다 사후 $(M=7.77)$ 가 높게 나왔으며 $t=$ -9.074, $p$ 〈.01로 통계적 유의한 차이가 있는 것으로 나타났다. 하위요인별로 분석하면 일일 행복 비율은 사전 $(M=40.35)$ 보다 사후( $M=52.69)$ 가 높게 나왔으며, $t=-2.319, p<.05$ 로 유의한 차이가 있는 것으로 나타났다. 일일 불행 비율은 사전 $(M=21.00)$ 보다 사후 $(M=13.85)$ 가 낮게 나타났지만 $t=1.487, p>.05$ 로 유의한 차이가 없는 것으로 나타났다. 일일 무감각 또한 사전 $(M=38.65)$ 보다 사후 $(M=33.46)$ 가 낮게 나타났지만 $t=.853, p>.05$ 로 통계적 유의한 차이가 없는 것으로 나타났다.

둘째, 선수 강점 인식 효과를 검증한 결과 사전 $(M=3.63)$ 보다 사후 $(M=4.00)$ 가 높게 나왔고, $t=-2.423, p<.05$ 로 유의한 차이가 있는 것으로 나타났다.

마지막으로 긍정 심리 개입 프로그램이 팀 상호작용에 미치는 효과를 살펴보면 크게 지도자 그리고 동료선수와의 상호작용으로 구분할

Table 3. Result of questionnaires

\begin{tabular}{|c|c|c|c|c|c|c|}
\hline \multicolumn{3}{|c|}{ Questionnaires } & $\begin{array}{l}\text { Pre/ } \\
\text { Post }\end{array}$ & $M$ & $S D$ & $t$ \\
\hline \multirow{8}{*}{$\begin{array}{l}\text { Happiness } \\
\text { measures } \\
\text { I }\end{array}$} & \multirow{2}{*}{ Part 1} & \multirow{2}{*}{ Happiness } & Pre & 5.35 & 1.70 & \multirow{2}{*}{$-9.074 * *$} \\
\hline & & & Post & 7.77 & 1.07 & \\
\hline & \multirow{6}{*}{ Part 2} & \multirow{2}{*}{ Happy } & Pre & 40.35 & 22.83 & \multirow{2}{*}{$-2.319 *$} \\
\hline & & & Post & 52.69 & 17.85 & \\
\hline & & \multirow{2}{*}{ Unhappy } & Pre & 21.00 & 19.04 & \multirow{2}{*}{1.487} \\
\hline & & & Post & 13.85 & 14.92 & \\
\hline & & \multirow{2}{*}{ Neutral } & Pre & 38.65 & 20.13 & \multirow{2}{*}{.853} \\
\hline & & & Post & 33.46 & 18.10 & \\
\hline \multirow{2}{*}{\multicolumn{3}{|c|}{ Strength knowledge }} & Pre & 3.63 & .58 & \multirow{2}{*}{$-2.423^{*}$} \\
\hline & & & Post & 4.00 & .43 & \\
\hline \multirow{10}{*}{$\begin{array}{l}\text { Team } \\
\text { interaction }\end{array}$} & \multirow{2}{*}{\multicolumn{2}{|c|}{$\begin{array}{l}\text { Coach-athlete } \\
\text { communication }\end{array}$}} & Pre & 3.01 & .90 & \multirow{2}{*}{-.797} \\
\hline & & & Post & 3.19 & .71 & \\
\hline & \multirow{2}{*}{\multicolumn{2}{|c|}{$\begin{array}{l}\text { Coach-athlete } \\
\text { assimilation }\end{array}$}} & Pre & 3.40 & .90 & \multirow{2}{*}{-.630} \\
\hline & & & Post & 3.56 & .85 & \\
\hline & \multirow{2}{*}{\multicolumn{2}{|c|}{$\begin{array}{l}\text { Athlete-athlete } \\
\text { devotion }\end{array}$}} & Pre & 3.68 & .49 & \multirow{2}{*}{$-2.717 *$} \\
\hline & & & Post & 4.06 & .50 & \\
\hline & \multirow{2}{*}{\multicolumn{2}{|c|}{$\begin{array}{l}\text { Athlete-athlete } \\
\text { assimilation }\end{array}$}} & Pre & 3.68 & .42 & \multirow{2}{*}{$-3.838 * *$} \\
\hline & & & Post & 4.12 & .43 & \\
\hline & \multirow{2}{*}{\multicolumn{2}{|c|}{$\begin{array}{l}\text { Athlete-athlete } \\
\text { communication }\end{array}$}} & Pre & 3.67 & .50 & \multirow{2}{*}{$-3.858 * *$} \\
\hline & & & Post & 4.15 & .53 & \\
\hline
\end{tabular}

수 있다. 먼저 지도자와 소통은 사전 $(M=3.01)$ 보다 사후 $(M=3.19)$ 가 높게 나타났고, $t=-.797, p>.05$ 로 통계적 유의한 차이가 없는 것으로 나타났다. 하위요인 지도자와 동화도 사전 $(M=3.40)$ 보다 사후 $(M=3.56)$ 가 높게 나타났지만 $t=-.630, p>.05$ 로 통계적 유의한 차이가 없는 것으로 나타났다. 동료 선수와의 상호작용 하위요인을 보면 동료 선수와의 헌신은 사전 $(M=3.68)$ 보다 사후 $(M=4.06)$ 가 높게 나왔으며 $t=-2.717, p<.05$ 로 유의한 차이가 있는 것으로 또한 하위요인 동료선수와 동화도 사전 $(M=3.68)$ 보다 사후 $(M=4.12)$ 가 높게 나왔으며 $t=-3.838, p$ 〈.01로 유의한 차이를 보였다. 하위요인 동료선수와 소통 역시 사전 $(M=3.67)$ 보다 사후 $(M=4.15)$ 가 높게 나와 $t=-3.858, p<.01$ 로 유의한 차이가 나타났다.

\section{2) 질적 분석: 경험보고서 및 심층 면담}

본 연구에서 개발한 프로그램 적용 효과 검증을 위해 마지막 회기 종결 후 경험보고서와 프로그램 평가지 작성을 요청하였다. 이후 선수 대상 심층면담을 진행하여 기억에 남는 경험과 느낀 점이 무엇인지 중점으로 추가 분석을 하였다. 프로그램을 통해 나타난 효과는 긍정심리, 강점 인식 및 활용, 긍정적 상호작용, 팀 응집력 순으로 나타났다.

\section{(1) 긍정 심리}

경험보고서에서 긍정심리 세부 내용은 긍정적 사고, 행복감, 심리적 환기, 긍정적 팀 분위기로 나타났다. 프로그램 전후로 자신이 가지고 있던 부정적 생각들이 긍정적으로 변했고, 팀원을 긍정적으로 바라보게 되었다고 하였다. 서로 강점을 찾아주고 칭찬해주며 좋은 생각들을 할 수 있게 되었고, 실천과제를 통해 지인들에게도 감사함을 표현하는 과정 속에서 행복감을 느꼈다고 답하였다. 공지 사항을 부착하던 기숙사 복도 게시판을 팀원 사진으로 꾸미고, 기존 팀 세레머니를 새롭게 바꾸는 활동은 시즌 기간이 지루해질 때쯤 색다른 변화를 줄 수 있어 일종의 심리적 환기를 느꼈다고 하였다. 이러한 내용에서 프로그램을 통해 긍정적 정서를 느끼는 계기가 되었음을 유추할 수 있다. 그리고 다양한 활동을 하면서 팀에 좋은 활력으로 작용하여 분위기가 좋아진 것 같다고 답하였다.

운동 외에 여러 가지 프로그램 활동을 팀원이 함께 하면서 개인 가치관과 팀원, 팀을 바라보는 태도가 긍정적으로 변하는 경험을 하였고, 이는 팀 분위기에 긍정적 영향을 미칠 수 있음을 의미한다. 면담을 통해 도출된 ‘긍정 심리’ 대표적인 내용은 다음과 같다.

“저는 팀 세레머니를 바꾼 활동이 가장 좋았는데 팀 분위기가 뭔가 전환되는 느낌이랄까. 원래 있었던 것보다 뭔가 기분이 더 좋고, 우리끼리 뭔가를 만들 어서 그런지 다른 느낌이 들어서 좋았다고 생각해요." (A 선수)

“저희가 1년 동안 어땠는지 항상 기억 속에서만 있었는데 사진을 보면서 다시 좋았던 기억이 생각나고 약간 기분이 좋게 올 한 해도 잘 보냈구나 싶고, 생각 보다 추억도 없었던 것 같고, 별 것 없었던 것 같았는데 같이 놀았던 사진, 전지 훈련 갔을 때 사진, 동기들끼리 어울린 사진을 보면서 뭔가 그땐 이런 기분으 로 보냈구나. 다시 기억나고, 힘든 부분이 있었어도 잘 지냈구나 싶어서 좋았 어요. 예전보다 복도가 애들도 더 밝아진 느낌이랄까. 복도 지나가다가도 이빨 닦다가도 사진을 보고 하는 모습을 보니까 다 좋아하는 것 같아요." (D선수)

(2) 강점 인식 및 활용

경험보고서에서 강점 인식 및 활용 세부 내용은 개인 및 팀원 강점 
인식으로 나타났다. 평소 개인 강점에 대해 다룰 기회가 별로 없었고, 부족한 부분을 보완하는 것에 초점을 두었지만 프로그램을 통해 생각해보는 계기가 되었다고 하였다. 강점 인식에서 끝나지 않고, 강점을 활용하는 이야기까지도 탐색하였다. 불안감을 느낄 때 또는 경기가 안 풀리거나 컨디션이 좋지 않은 상황에서 강점을 생각하며 용기를 얻을 수 있었다고 하였다.

즉, 선수들에게 강점을 파악하는 과정은 자신에 대해 알아보는 기회를 제공하고, 자신감 향상과 심리적 안정감을 줄 수도 있음을 의미한다. 또한 팀원의 강점을 말해주는 과정으로 미처 생각하지 못 한 자신에 대해 재발견할 수 있었다고 답하였다. 이러한 내용은 프로그램이 개인과 더불어 팀원의 강점을 들여다보고, 서로 감사함과 긍정적인 정서까지 느낄 수 있도록 했다는 것을 의미한다. 면담을 통해 도출된 '강점 인식 및 활용' 대표적인 내용은 다음과 같다.

"강점도 찾아주고, 칭찬 해주면서 자기가 몰랐던 것에 대해서도, 상대에 대해 서도 몰랐던 것을 알게 되었고, 서로 이야기도 많이 할 수 있어서 팀 분위기가 좋아진 것 같아요." (B선수)

"강점 찾기를 하거나 하면 겉으로는 좀 오글거려도 속으로는 또 내심 뿌듯하 고 그렇거든요. 그런 것이 팀 내에서 생기니까 서로한테 긍정적인 효과로 나오 는 것 같아요. 그러다 보니까 프로그램을 안 할 때도 일상생활에서도 생각하게 되는 것 같아요." (C선수)

\section{(3) 긍정적 상호작용}

경험보고서에서 나타난 긍정적 상호작용 세부 내용은 의사소통, 이해이다. 프로그램을 통해 평소 팀원과 말하지 못 했던 것을 해보는 기회가 되고, 서로에 대해 알 수 있었다고 하였다. 이는 여러 활동을 하면서 팀원을 서로 이해하게 되는 긍정적 상호작용이 일어났음을 의미한다.

프로그램 참여로 좋은 분위기에서 대화할 수 있었고, 편지 쓰기 같은 활동으로 팀원과 교류할 수 있게 되었다고 말한 점으로부터 상호작용 증진 효과를 알 수 있다. 회기 주제에 대해 아이디어를 공유하고, 팀원 의견을 경청하면서 의사소통에 긍정적 변화가 생겼음을 탐색할 수 있다. 선수 심층면담을 통해서 나타난 '긍정적 상호작용' 내용은 다음과 같다.

"아무래도 저학년이 고학년을 어려워하는 부분이 있었어요. 서로 장난도 많이 치면서 팀원끼리 말이 많아지니까 선배에 대한 어려움이 허물어지고, 원래는 물어보라고 해도 잘 안 물어보곤 했는데 먼저 조언도 구하고, 사이가 더 좋아 진 것 같아요." (A 선수)

"원래 남자들은 그렇잖아요. 표현하고 말하는 걸 오글거려 하는데 익명으로 편지 쓰니까, 처음에 그 편지 받았을 때 '어, 진짜 누구지?' 했어요. 알고 보니 까 바로 옆에서 쓰던 선수더라고요. 익명이라서 더 솔직하게 쓸 수 있었고, 그 래서 더 고맙고 좋았어요." (C선수)

\section{(4) 팀 응집력}

경험보고서에서 팀 응집력 세부 내용은 결속력, 친밀감으로 나타났다. 팀원들과 친해질 수 있는 기회가 되었으며 우정 등이 좋아진 것 같다고 답하였다. 또한 단합이 잘 되어 링크장에서도 긍정적으로 작용하였고, 함께 하는 활동들을 통해 결속된 팀 분위기 조성에 도움이 되었다고 하였다.

다양한 활동을 하면서 팀원과 유대관계를 형성하게 되었으며
끈끈해지고 돈독해졌다는 표현을 통해 선수들의 팀 응집력 향상을 발견할 수 있다. 또한 팀원의 소중함과 애착을 느껴 팀에 대한 인식이 긍정적으로 작용했음을 의미한다. 선수 대상 심층면담을 통해 나타난 ‘팀 응집력' 내용은 다음과 같다.

"뭔가 전통이라 해야 하나 그런 것들이 팀 자체에서 좀 더 있었으면 생각했어 요. 그런데 팀 색깔을 확실하게 정해서 한 것이 좋았어요.” (C선수)

“프로그램 통해서 서로 의견도 알게 되고, 좀 더 저희가 원하는 '원팀(one team)'의 분위기로 가는데 도움이 되지 않았나 생각이 들어요." (D선수)

\section{3) 질적 분석: 프로그램 평가지}

추가적으로 프로그램에 대한 세부 평가를 위해 마지막 회기 종결 후 프로그램 참여 선수 대상으로 평가지를 작성할 수 있도록 하였다. 특히 "프로그램에 대해 건의하고 싶은 사항, 활동들이 있다면 무엇인가요?" 질문에 대해 "6회기 프로그램을 더 했으면 좋겠다, 몸으로 움직이는 활동이 많아지면 좋을 것 같다.”와 같은 답변은 음미하기 활동의 만족감과 아쉬움을 의미한다. 추후 프로그램 보완 시 이와 같은 내용을 고려한다면 선수 프로그램 만족도가 높아질 수 있다는 잠재성을 탐색할 수 있다.

\section{논의}

본 연구 목적은 대학 아이스하키 팀 긍정 심리 개입 프로그램을 개발하여 현장에 적용하고 그 효과를 검증하는 것이다. 본 연구에서 얻은 결과를 토대로 논의하면 다음과 같다.

팀 스포츠는 자기 지향적이면서 그룹 지향적 정체성, 목표, 감정이 복잡하게 얽혀 있는 특징을 가진다(Campo et al., 2019). 긍정심리학은 적용 대상에 따라 다양한 응용이 가능하고, 문화적 요인으로 여러 가지 결과가 도출(Hendriks et al., 2020; Seligman, 2011)될 수 있다. 이 내용을 바탕으로 팀은 역동성과 다양한 변수들이 존재하는 특수성에 유의하며 지속적인 전문가 회의를 통해 프로그램 구성, 회기, 세부 활동을 개발, 수정, 보완하였다. 프로그램 활동 진행 중 소외되는 구성원이 없을지 예민한 주제나 프로그램 이후 부작용이 될 만한 요소 등 여러 측면을 고려하였다.

이때 대학 아이스하키 선수들의 실제 스포츠 현장과 팀 훈련 및 일정에서 일어나는 팀 상호작용, 생활 모습을 직접 알아보기 위해 참여관찰을 하였다. 참여관찰은 연구 상황 이해를 높이고 일상적인 내용들을 살펴보는데 효과적이며 질적 연구 측면에서 프로그램 내용 구성을 현장에 적합하도록 하는 방법이다(Kang, 2015). 이러한 단계는 선행 연구(Kim \& Lee, 2019; Kwon et al., 2016)에서도 제시된 과정으로 추후 프로그램 적용 시 선수들과 라포(rapport) 형성에 도움이 되고, 현장 수용도를 높일 수 있다. 또한 시작 단계부터 편안함과 믿음 수준이 높은 집단에서는 상담에 도움이 된다고 보고된 점으로부터(Jacobs et al., 2016) 프로그램 개발에 있어 참여관찰의 중요성과 의미를 찾을 수 있다.

또한 프로그램 개발 과정에서 프로그램 체계성을 위해 긍정심리학을 조직에 적용한 긍정조직학의 개념을 반영하였다. 긍정조직학이란 긍정심리학과 조직 이론 연계 학문이다. 조직에서 발생하는 긍정적 현상에 중점을 둔다. 문제 해결이나 약점 관리 보다 강점과 역동성에 대해 연구하는 분야이다(Cameron et al., 2003). 특히 긍정 정서 
증진은 조직 구성원에게 장점이 될 수 있어 조직 발전을 추구하는 방법론으로 활용한다(Oades et al,, 2017).

팀 스포츠 운동선수에게 팀은 결국 일터이자 조직이다. 팀이란 협동적인 관계를 바탕으로 공동의 목표 달성을 위해 상호작용을 하는(Kim \& Lee, 2019) 집합체로 조직학 이론과 상당한 유사성을 가진다. 또한 긍정심리학 기반 강점 인식, 팀 상호작용, 행복감을 다루는 프로그램 목적과 부합하는 학문이라 판단하여 긍정조직학 개념을 활용하였다. 세부 프로그램 목표를 팀 생활 속에서 긍정적인 요소 발견으로 수립하였기 때문에 긍정조직학 '4D-Process' 모형을 참고하였다. 발견하기 단계를 2단계로 구분하여 최종 프로그램을 구성하였다. 기존 모형(Van Zyl et al., 2016)을 연구 목적에 맞게 재구성하여 프로그램 활동들이 팀에 적합하도록 개발하였다. 개인 중심으로 이루어지는 활동과 개인 행복에 초점을 맞추는 선행연구(Lee \& Shin, 2017; Lim et al., 2019)와 차별화되는 점이다.

대학 아이스하키 팀을 위한 긍정 심리 개입 프로그램 개발 시 요구분석으로부터 활용한 구성 요인 상호작용, 강점 활용, 인간관계, 긍정심리 등은 선행연구에서 개입 후 나타난 효과와 관련성이 높았다(Bolier et al., 2013; Chen, 2013; Donaldson et al., 2019; Gabana, 2019; Winslow et al., 2017). 팀 생활 시 대회 우승이 가장 큰 행복감 요인으로 나타났다. 팀원과 같이 시간을 보내고 다양한 활동을 통한 상호작용 역시 팀 생활에서 행복을 느끼게 해주는 구성 요인 중 높은 비중을 차지하였다. 여기서 주목해야 할 내용은 심리적 손상 경험은 오히려 대회 패배보다 팀원 사이에서 발생하는 갈등 및 불화라고 하였다. 이와 더불어 팀이 행복해지기 위해서는 단합, 팀 분위기와 같은 팀 요인, 존중 및 배려가 우선적으로 필요하다고 답하였다. 결국 연구 대상자인 아이스하키 선수들은 우승도 중요하지만 무엇보다 팀원 상호작용 증진과 긍정적 팀 분위기 조성을 필요로 하고 있다는 것을 말해주며 긍정 심리 개입 프로그램 개발의 적합성을 뒷받침 해준다.

이러한 요구 분석 내용을 프로그램에 반영하기 위해 3회기(팀 강점 찾기), 5 회기(감사하기), 8 회기(공유하기)를 개발하였다. 팀 강점을 찾으며 소속감을 느끼고, 서로의 마음을 표현하는 기회를 제공하였다. 편지 쓰기 활동으로 감사함을 전하며 팀원과 상호작용을 높이도록 하였다. 또한 그동안 찍었던 사진들을 모아 추억을 공유하는 시간을 통해 유대감 형성과 긍정적인 팀 분위기를 구축할 수 있도록 하였다. 선행연구(Lee \& Shin, 2017; Gabana, 2019)에서도 감사한 대상에게 마음을 표현하는 활동은 행복, 자아존중감, 정서, 사회적 연결에도 긍정적으로 작용했다는 연구 결과와 일치한다.

요구분석에서 새로운 구성 요인으로 심리적 환기 내용을 도출하였다. 전문가 회의를 통해 선수들은 훈련 강도가 더해져 힘들 수도 있는 해외 전지훈련에서 왜 행복감을 경험하는 것일까에 대해 분석한 결과 환경으로부터 변화, 일상의 달라짐에 의한 것이라 판단하였다. 즉, 운동과 학업으로 쳇바퀴처럼 반복되는 일상을 보내는 대학 운동선수들에게 특히 환기의 경험은 매번 비슷한 생활 패턴을 가지기 때문에 행복을 위해 고려해야 하는 요인으로 분석하였다. 심리적 환기 경험은 긍정적인 심리를 끌어 올릴 수 있고, 새롭고 다양한 활동을 팀원과 함께 할 때 상호작용이 증진되어 결국 행복감으로 이어질 가능성이 높을 것이라 예상하였다. 이와 함께 강점 찾기 활동을 통한 재발견 기회 역시 심리적 환기를 경험할 수 있다 판단하여 2 회기(개인과 팀원 강점 찾기), 3 회기(팀 강점을 찾아 세레머니 만들기), 6회기(자유로운 하키 훈련하기), 8 회기(복도 게시판을 팀 사진으로 꾸미기) 프로그램을 구성하였다.
최고 수행을 위해 부족한 부분을 보완하려고 노력하는 선수들에게 강점 찾기 기회는 자신에 대해 긍정적인 측면을 생각해보는 계기와 새로운 경험이 될 수 있을 것이라 판단하였다. 이때 팀원이 강점을 같이 발견해줄 때의 긍정 정서 강화 효과 이점까지도 기대하였다. 강점은 개인과 집단 행복 증진을 위해 사용할 수 있는 방법이기 때문이다(Biswas-Diener, 2011). 또한 새로운 팀 세레머니 개발과 팀원 사진을 복도 게시판에 꾸미는 활동은 일상적으로 당연하게 하던 행동 패턴과 익숙한 공간에 작은 변화를 주고자 하는 목적을 가졌다. 아이스링크장, 기숙사에서도 환기의 경험을 제공하여 긍정 정서 증진을 목표로 하였다. 6 회기처럼 자유롭게 하키 훈련을 할 수 있는 활동을 고안한 이유도 마찬가지이다. 운동선수들은 대부분 정해진 훈련에 따라야 하는 환경에 놓여있는 점을 고려하였다. 새로운 미니 게임 훈련을 통해 종목 자체에 몰입하고, 즐거움을 느낄 수 있도록 하였다. 행복한 활동은 긍정적인 사고를 발전시켜주기 때문에(Nam, 2017) 이러한 프로그램 구성들은 팀 상호작용을 높이며 결과적으로 행복감 증진에 도움이 될 것이라 판단하였다. 창의적이고 다양한 활동을 하면 개인의 긍정적 자원을 찾아볼 수 있고, 그 과정을 통해 일종의 좋은 감정인 심리적 환기와 관련하여 횔씬 더 많은 개인 정서 자산 생산 시스템 구축이 가능하다(Meyers et al., 2013). 사소하지만 긍정적인 경험은 즐거움 탐색 능력을 향상시킬 수 있고, 긍정 정서 지속성이 증가하여 최상의 수행을 위해서도 활용할 수 있다는 결과와 관련성이 높다(Seligman et al., 2006; Kwon \& Yun, 2012).

본 연구에서 개발한 프로그램을 현장에 적용한 효과 검증은 프로그램 사전 사후로 3 가지 검사지를 통해 양적 효과 검증을 하였다. 또한 프로그램 종결 이후 경험보고서 및 프로그램 평가지 작성과 선수 심층면담을 실시하였다. 긍정 심리 개입 프로그램에 대한 적용 결과를 통합적으로 논의하면 다음과 같다.

첫째, 긍정 심리 개입 프로그램은 대학 아이스하키 팀에서 긍정적 사고, 행복, 심리적 환기와 같은 긍정 심리 증진 결과를 확인할 수 있었고, 프로그램 전후로 행복감에서 통계적 유의한 차이가 있는 것으로 나타났다. 즉, 긍정 심리 개입은 선수들의 행복 수준을 높일 수 있음을 의미한다. 긍정 심리와 관련한 선행연구(Chakhssi et al.,2018; Seligman, 2019)에서 긍정적인 감정과 생각을 높일 수 있는 활동들은 행복감과 주관적 웰빙 발전을 가져온다는 결과와 유사하다. 이러한 내용은 팀원 활동을 통해 친밀감과 결속력을 느끼면서 긍정적 정서 교류를 할 수 있었고, 팀 분위기로 이어져 행복감에 영향을 미친 것으로 유추할 수 있다. 공동의 목표를 위해 팀 구성원들이 적극적인 소통과 공통된 경험하면서 긍정적 팀 분위기를 형성할 때 정서 공유 및 공감 가능성이 높다는 내용과 일치한다(Rhee \& Ko, 2017; Parkinson et al., 2005). 따라서 팀원과 긍정적인 경험을 함께 할 수 있는 기회를 제공하고, 상호작용을 높일 경우 행복감 증진으로 연결될 수 있음을 시사한다.

둘째, 긍정 심리 개입 프로그램은 프로그램 시행 전후로 팀 상호작용 특히 동료 선수와 동화, 소통, 헌신에서 통계적 유의한 영향을 미치는 것으로 나타났다. 하지만 지도자와의 동화, 소통은 평균적으로는 증가하는 경향을 보였으나 통계적으로는 유의미한 차이가 나타나지 않았다. 이러한 결과는 '프로그램 참여도'로부터 발생할 수 있는 차이로 분석 가능하다. 학기, 시즌 중에 개입된 프로그램으로 지도자와 코칭스태프는 여러 업무에 의해 전반적인 참여가 어려운 상황이었다. 물론 Kim과 Lee(2019) 연구에서도 선수 대상 커뮤니케이션 프로그램을 진행하여 스포츠 우리성의 유의미한 증가를 보여짔다. 하지만 감독을 
포함한 코치진은 선수들의 감정, 인식, 행동 형성에 미치는 영향이 크다(Chen, 2013). 이들로부터 더 많은 사회적 지지를 받았을 때 선수 심리적 복지 증진에 도움이 될 수 있기 때문에 감독 및 코칭스태프의 프로그램 참여도를 높이는 노력이 요구된다. 추가적으로 긍정 심리 개입 프로그램 효과에서 나타난 의사소통, 이해를 의미하는 긍정적 상호작용 그리고 결속력, 친밀감과 같은 팀 응집력 향상은 팀 빌딩(team-building) 프로그램과도 연계할 수 있는 가능성을 보여준다. 팀 빌딩은 조직심리학에서 발전한 전략으로 팀 구성원 대인 관계에 영향을 주며 조직의 응집력과 효율성 향상을 목적으로 하는 중재 기법이다(Kim \& Kim, 2012). 긍정 심리 개입 활동을 통해 상호작용을 증진시켰듯이 팀 빌딩 또한 팀 분위기 개선에 도움이 되는 프로그램이다. 때문에 중첩되는 내용이 있어 상호보완적 활용 가능성이 높을 것으로 사료된다. 따라서 이러한 결과를 정리하면 팀을 위한 긍정 심리 개입 프로그램은 지도자와 코칭스태프 프로그램 참여 필요성과 팀 빌딩 전략과의 관련성을 고려해볼 수 있다.

셋째, 긍정 심리 개입 프로그램은 아이스하키 선수 강점 인식에 통계적으로 유의한 영향을 미치는 것으로 나타났다. 이뿐만 아니라 경험보고서와 심층면담에서도 선수들이 강점 인식에서 그치지 않고 스스로 경기 도중 강점을 활용하고, 팀원에 대한 이해의 계기를 제공하였다. 팀 강점 찾기 회기에서 새로운 팀 세레머니를 생각해보는 활동을 한 후 선수들이 실제 경기 현장에서 자발적으로 이를 적용하거나 경기가 잘 풀리지 않고, 컨디션이 좋지 않을 때 강점을 생각하며 침착하게 할 수 있었다는 등 여러 측면에서 강점 활용 결과가 도출되었다. 우수 선수일수록 자신이 가진 강점을 잘 알고 있으며 이를 인지했을 때 자신감 상승으로 이어질 수 있다는 강점 인식 및 활용 선행연구(Park et al., 2018)와 유사한 결과이다. 그리고 우수 선수는 강점을 적극적으로 활용하면서 경기 중 심리적 어려움을 효과적으로 극복할 수 있으며 긍정적인 경기 운영이 가능하다. 긍정심리학에서 말하는 강점은 심리적 안녕감, 자기 효능감, 긍정 정서, 희망과도 높은 관련성을 가진다(Bolier et al., 2013; Chakhssi, et al., 2018; Hendriks et al., 2020). 또한 SWOT를 활용해 자신의 장점을 인식하고 개발하여 선수에게 심리기술 이점 효과가 있었다는 결과(Park \& Shin, 2017) 역시 본 연구 결과와 일치하는 내용이다. 즉, 선수들에게 강점은 경기 중 또는 생활 중 긍정적인 영향을 미쳐 강점 활용에 따른 성공 경험과 함께 자신감 등 심리적 효과를 볼 수 있다. 이는 원활한 경기 흐름을 갖지 못 할 때 미래를 낙관적으로 생각하고 심리적 안정감을 갖추도록 도와줄 수 있음을 시사한다.

본 연구를 통해 얻은 결과들을 종합하여 논의하면 대학 아이스하키 팀을 위한 긍정 심리 개입 프로그램은 선수 개인 강점 인식 계기를 제공해주고, 팀원 상호작용 증진뿐만 아니라 행복감 향상 결과가 나타났다. 이러한 요인들이 함께 작용하면 긍정적인 팀 분위기 조성과 팀 단합에 따른 긍정적 팀 경기력을 기대해볼 수 있기 때문에 앞으로 스포츠 현장에서 팀을 위한 긍정 심리 개입 프로그램 활용 가능성을 찾아볼 수 있다.

물론 본 연구 프로그램 적용 대상 팀인 A대학교 아이스하키 팀 경우 프로그램 진행 당시 U-리그 시즌 경기 내용과 결과가 우수했기 때문에 프로그램을 하면서 느낀 효과, 결과, 만족감은 플라세보(placebo) 작용과의 관련성을 배제할 수 없다.

하지만 본 연구를 통해 개발한 프로그램은 국내 대학 아이스하키 팀 다수를 대상으로 구성한 것이다. 또한 문헌고찰, 요구분석, 참여관찰, 전문가 회의 등 체계적 절차에 의거했기 때문에 프로그램의 신뢰도와
타당성은 확보된 것으로 판단한다. 따라서 다른 팀에게도 효과가 있을지에 대해 연구 적용 범위를 확대하여 추가적 검증을 시도해볼 필요가 있으며 팀을 대상으로 하는 긍정 심리 개입 프로그램에 대한 적극적인 연구 시행이 요구된다.

\section{결론 및 제언}

본 연구에서 얻은 결론은 첫째, 프로그램 개발을 위해 실시한 요구분석 구성 요인 탐색 결과 선수들이 팀원과 시간을 같이 보내거나 화합하는 상호작용을 통해 행복감을 느끼고, 팀원과의 갈등 및 불화로 인해 심리적 손상 경험을 한다고 하였다. 또한 서로 존중하고 배려할 때 비로소 팀이 행복해질 수 있다는 요인들이 도출되었다.

둘째, 국내 대학 아이스하키 팀을 위한 긍정 심리 개입 프로그램 구성 요인은 상호작용, 강점 활용, 결속력, 심리적 환기, 인간관계, 휴식 및 다양한 활동, 팀 요인, 존중 및 배려, 신뢰 및 감정 표현, 긍정 심리 요인을 반영하여 총 5단계, 10 회기 프로그램을 개발하였다.

셋째, 긍정 심리 개입 프로그램은 선수의 행복감, 강점 인식, 팀 상호작용에 대해서도 통계적으로 유의한 차이가 나타났으며 긍정심리, 강점 인식 및 활용, 긍정적 상호작용, 팀 응집력 효과도 도출되었다.

본 연구 논의 및 결과와 관련하여 후속 연구에서 고려해야 할 수 있는 내용에 대해 제언하면 다음과 같다.

첫째, 본 연구는 팀 선수들을 대상으로 조사하고, 분석한 내용을 토대로 프로그램을 개발하여 적용하였다. 이에 따라 프로그램 적용 전후 동료 선수들과의 소통, 동화, 헌신이 향상되는 경향을 보였다. 반면 지도자와의 소통, 동화는 평균적으로 증가했지만 통계적으로는 유의미한 차이가 도출되지 않았다. 시즌 중 개입이라는 제한점으로 인해 지도자와 코칭스태프들의 참여가 어려웠다. 하지만 코치진은 선수들의 정서나 행동에 미치는 영향이 크다는 연구 내용(Chen, 2013)과 같이 후속 연구에서는 지도자 참여가 가능한 프로그램 개발 및 보완을 고려해볼 필요가 있다. 팀 구성원 전원이 함께 프로그램을 참여한다면 동료 선수뿐만 아니라 지도자와 선수 사이에도 더욱 긍정적인 효과를 미칠 것이라 생각한다.

둘째, 본 연구에서는 아이스하키 선수 대상으로 연구를 진행했기 때문에 다른 종목의 팀에게 적용하면 제한점이 있을 수 있다. 후속 연구에서는 종목마다 특성과 개성을 고려한 활동으로 구성하여 프로그램 개발과 효과를 검증하는 연구가 시도되어야 할 것이다.

셋째, 본 연구에서는 프로그램 효과를 분석하기 위해 프로그램 적용 전후로만 측정하였다. 선행연구(Kwon et al., 2016)에서 프로그램 적용 이후 부분적인 지속 효과가 있었지만 전체적으로 감소하는 양상을 보였다고 밝혔다. 따라서 프로그램 효과는 시간 경과와 여러 환경적 요인들로 지속되지 않을 수도 있기 때문에 정기적인 프로그램 적용과 장기적인 관리가 이루어져야 할 것이다. 


\section{참고문헌}

Antoine, P., Dauvier, B., Andreotti, E., \& Congard, A. (2018). Individual differences in the effects of a positive psychology intervention: Applied psychology. Personality and Individual Differences, 122, 140-147.

Biswas-Diener, R. (2011). Positive psychology as social change. New York, NY: Springer.

Bolier, L., Haverman, M., Westerhof, G. J., Riper, H., Smit, F., \& Bohlmeijer, E. (2013). Positive psychology interventions: a meta-analysis of randomized controlled studies. BMC public health, 13(1), 119.

Bryant, F. B., \& Veroff, J. (2007). Savoring: A new model of positive experience. Mahwah, NJ: Erlbaum Associates.

Cameron, K. S., Dutton, J. E., \& Quinn, R. E. (2003). An introduction to positive organizational scholarship. Positive Organizational Scholarship, 3(13), 2-21.

Campo, M., Champely, S., Louvet, B., Rosnet, E., Ferrand, C., Pauketat, J. V., \& Mackie, D. M. (2019). Group-based emotions: Evidence for emotion-performance relationships in team sports. Research quarterly for exercise and sport, 90(1), 5463.

Cannon, M. D., \& Edmondson, A. C. (2005). Failing to learn and learning to fail(intelligently): How great organizations put failure to work to innovate and improve. Long range planning, 38(3), 299-319.

Chakhssi, F., Kraiss, J. T., Sommers-Spijkerman, M., \& Bohlmeijer, E. T. (2018). The effect of positive psychology interventions on well-being and distress in clinical samples with psychiatric or somatic disorders: A systematic review and metaanalysis. BMC psychiatry, 18(1), 1-17.

Chamberlain, J. J., Benson, A. J., \& Hall, C. R. (2019). The relations between newcomer integration processes and youth athletes' perceptions of the group environment in competitive hockey. Journal of Exercise, Movement, and Sport (SCAPPS refereed abstracts repository), 51(1), 87-87.

Chen, L. H. (2013). Gratitude and adolescent athletes' well-being: The multiple mediating roles of perceived social support from coaches and teammates. Social Indicators Research, 114(2), 273285.

Cheon, S. M., \& Kim, B. J. (2019). The Development and Characteristics of Super Psychological Skills in Elite Athletes. Korean Journal of Sport Psychology, 30(1), 129-148.

Choi, J. H., \& Kim, I. G. (2011). The Relationship among Role Clarity, Role Satisfaction, Team Cohesion, and Athlete Satisfaction in Team Sports. Korean Journal of Sport Management, 16(5), 1-15.

Choi, S. H., \& Song, Y. G. (2017). The Effects of the Performance and Psychological Skill Strategy in the Effectiveness of Psychological Skill Training on the Archery Player in Middle School. The Korean Journal of Physical Education, 56(3), 99-114.
Compton, W. C., \& Hoffman, E. (2019). Positive psychology: The science of happiness and flourishing. LA: SAGE Publications.

Dolphin, K. E., Steinhardt, M. A., \& Cance, J. D. (2015). The role of positive emotions in reducing depressive symptoms among Army wives. Military Psychology, 27(1), 22-35.

Donaldson, S. I., Lee, J. Y., \& Donaldson, S. I. (2019). Evaluating positive psychology interventions at work: A systematic review and meta-analysis. International Journal of Applied Positive Psychology, 4(3), 113-134.

Fordyce, M. W. (1972). Happiness, its daily variation and its relation to values. Dissertation Abstracts International 33, $1266 B$. University Microfilms, (72-23), 491.

Gabana, N. T. (2019). Gratitude in Sport: Positive Psychology for Athletes and Implications for Mental Health, Well-Being, and Performance. In Theoretical Approaches to Multi-Cultural Positive Psychological Interventions (pp. 345-370). Springer, Cham.

Gelso, C. J., Nutt Williams, E., \& Fretz, B. R. (2014). Counseling psychology. Washington (DC): American Psychological Association.

Govindji, R., \& Linley, P. A. (2007). Strengths use, self-concordance and well-being: Implications for strength coaching and coaching psychologists. International Coaching Psychology Review, 2(2), 143-153.

Guo, Y. F., Zhang, X., Plummer, V., Lam, L., Cross, W., \& Zhang, J. P. (2017). Positive psychotherapy for depression and self-efficacy in undergraduate nursing students: A randomized, controlled trial. International Journal of Mental Health Nursing, 26(4), 375-383.

Hefferon, K., \& Boniwell, I. (2011). Positive psychology: Theory, research and applications. McGraw-Hill Education.

Hendriks, T., Schotanus-Dijkstra, M., Hassankhan, A., de Jong, J., \& Bohlmeijer, E. (2020). The efficacy of multi-component positive psychology interventions: A systematic review and metaanalysis of randomized controlled trials. Journal of Happiness Studies, 21, 357-390.

Ho, H. C., Yeung, D. Y., \& Kwok, S. Y. (2014). Development and evaluation of the positive psychology intervention for older adults. The Journal of Positive Psychology, 9(3), 187-197.

Hwang, J. W., \& Kwon, S. M. (2019). The Mediation Effects of Team Interaction on the Relationship between Coaching Behaviors and Perceived Performance by College Soccer Players. Journal of Coaching Development 21(1), 3-13.

Jacobs, E., Schimmel, C., Masson, R. L., \& Harvill. (2016). Group counseling: Strategies and skills (8th ed.). Boston, MA: Cengage Learning.

Jeong, S. H., \& Kim, H. Y. (2014). Verification of Relationship of Multidimensional Perfectionism Orientation, Stress, Coping Styles, Social Anxiety in College Athlete. The Korean Society of Sports Science, 23(1), 513-524.

Kang, E. S. (2015). A Research on Participatory Observation of Sport Activities as to Qualitative Research. The Korea Journal of 
Sports Science, 24(4), 49-62.

Kang, H. W., \& Yang, H. Y. (2017). Development and Validation of Sport Team Interaction Scale. Korean Journal of Sport Psychology, 28(1), 23-32.

Kim, B. J., \& Lee, D. H. (2019). Development and Application of Team Communication Program and it's Effects on Sport Weness and Achievement. Korean Journal of Sport Psychology, 30(1), 55-68.

Kim, O. J., Kim, O. K., \& Park, D. H. (2019). The Effects of the Psychological Process and Teamwork Factors of Handball Players on Team Cohesiveness. The Korea Journal of Sports Science, 28(1), 297-309.

Kim, Y. S. (2010). The Development of Sport Team-building Program for Youth Female Football Team. Korean Journal of Sport Psychology, 21(4), 139-152.

Kim, Y. S., \& Kim, B. J. (2012). The Change of Team Cohesion in a University Baseball Team by Applying Team-building Intervention. Korean Journal of Sport Science, 23(2), 334-342.

Kwon, O. J., \& Yun, Y. K. (2012). The Possibility of Adopting Savoring towards Physical Activity According to the Savoring Ways in Dance. Korean Journal of Sport Psychology, 23(2), 1-13.

Kwon, S. H., Choi, J. S., \& Yook, D. W. (2016). Development of a Communication Training Program and Application for a College Ice Hockey Team. Korean Journal of Sport Science, 27(4), 941956.

Lee, H. W., \& Shin. J. T. (2017). The effect of positive psychological intervention program on mood state, self-esteem and happiness of university student athletes: Exploratory studies. Korean Journal of Sport Science, 28(4), 1020-1033.

Lim, T. H., Oh, J. H., \& Jung, K. I. (2019). Effect of PST Using Positive Psychological Techniques on the Psychological Variables and Performance of a Rifle Shooter. Korean Journal of Sport Psychology, 30(3), 19-30.

Liu, W., Zhou, C., Ji, L., \& Watson, J. C. (2012). The effect of goal setting difficulty on serving success in table tennis and the mediating mechanism of self-regulation. Journal of Human Kinetics, 33, 173.

Lopez, S. J., Pedrotti, J. T., \& Snyder, C. R. (2018). Positive psychology: The scientific and practical explorations of human strengths. Sage Publications.

Louro, A. C., Fernández-Castro, J., \& Blasco, T. (2015). Is there a relationship between positive affect and quality of life in colorectal cancer patients?. Anales de Psicología/Annals of Psychology, 31(2), 404-413.

Mann, A., \& Narula, B. (2017). Positive psychology in sports: An overview. International Journal of Social Science, 6(2), 153-158.

Matthews M. D. (2017). Positive Psychology and Elite Sports Performance. Psychology Today.

Meyers, M. C., van Woerkom, M., \& Bakker, A. B. (2013). The added value of the positive: A literature review of positive psychology interventions in organizations. European Journal of Work and Organizational Psychology, 22(5), 618-632.

Moon, H. S., \& Hong, S. B. (2011). The development of sport demotivaton scale of elite athletes. Korean Journal of Sports Science, 20(6), 545-559.

Nam, S. G. (2017). Positive psychology. Paju: Yangseowon.

Nicholls, A. R., Polman, R. C., \& Levy, A. R. (2012). A path analysis of stress appraisals, emotions, coping, and performance satisfaction among athletes. Psychology of sport and exercise, 13(3), 263-270.

Oades, L. G., Steger, M., Delle Fave, A., \& Passmore, J. (Eds.). (2017). The Wiley Blackwell handbook of the psychology of positivity and strengths-based approaches at work. John Wiley \& Sons.

Park, J. Y., \& Shin, J. T. (2017). The Development of Positive Psychological Intervention Through Single Case Design for University Student Athlete Using Single Case Design. Journal of Wellness, 12(3), 413-422.

Park, J. Y., Kim, B. J., \& Kim, Y. S. (2018). The Strengths Knowledge and Strengths Use of Korean Elite Archers. The Korean Journal of Physical Education, 57(3), 79-89.

Parkinson, B. (1996). Emotions are social. British journal of psychology, 87(4), 663-683.

Parkinson, B., Fischer, A. H., \& Manstead, A. S. (2005). Emotion in social relations: Cultural, group, and interpersonal processes. New York: Psychology Press.

Rhee, S. Y., \& Ko, S. H. (2017). The Mechanisms, Antecedents and Outcomes of Shared Positive Affect and Its Application to Positive Organizational Scholarship. Korean Journal of Management, 25(2), 159-192.

Scholes, M. (2017). Positive psychology and sport. In Future directions in well-being (pp. 129-132). Springer, Cham.

Scutti, S. (2018). Michael Phelps: 'I am extremely thankful that I did not take my life'. CNN. Retrieved from https://edition.cnn. com/2018/01/19/health/michael-phelps-depression/index.html

Seligman, M. E. (2002). Positive psychology, positive prevention, and positive therapy. Handbook of positive psychology, 2(2002), 3-12.

Seligman, M. E. (2019). Positive Psychology: A Personal History. Annual Review of Clinical Psychology, 15, 1-23.

Seligman, M. E. P., Rashid, T., \& Parks, A. C. (2006). Positive psychotherapy. American psychologist, 61(8), 774-778.

Seligman, M. E., Steen, T. A., Park, N., \& Peterson, C. (2005). Positive psychology progress: empirical validation of interventions. American psychologist, 60(5), 410.

Seligman, M. E. P. (2011). Flourish: A new understanding of happiness and well being and how to achieve them. London: Nicholas Brealey Publishing.

Seo, J. Y. (2017). The depression of a footballer who is under pressure to win, anxiety and nervousness. JTBC. Retrieved from http:// news.jtbc.joins.com/article/article.aspx?news_id=NB11467250 
Tamminen, K. A., McEwen, C. E., \& Crocker, P. R. (2016). Perceived parental support, pressure, and the socialization of adolescent athletes' coping. International Journal of Sport Psychology, 47(4), 335-354.

Van Zyl, L. E., Stander, M. W., \& Odendaal, A. (Eds.). (2016). Coaching Psychology: Meta-theoretical perspectives and applications in multicultural contexts. Springer.

Weinzimmer, L. G., \& Esken, C. A. (2017). Learning from mistakes: How mistake tolerance positively affects organizational learning and performance. The Journal of Applied Behavioral Science, 53(3), 322-348.

White, M. A., \& Waters, L. E. (2015). A case study of 'The Good School:'Examples of the use of Peterson's strengths-based approach with students. The Journal of Positive Psychology, 10(1), 69-76.

Winslow, C. J., Kaplan, S. A., Bradley-Geist, J. C., Lindsey, A. P., Ahmad, A. S., \& Hargrove, A. K. (2017). An examination of two positive organizational interventions: For whom do these interventions work? Journal of Occupational Health Psychology, 22(2), 129-137.

Yu, S. L. (1988). The effect of a program to increase personal happiness: The fourteen fundamentals (Master's dissertation). Pusan National University, Busan, Korea. 


\title{
대학 아이스하키 팀을 위한 긍정 심리 개입 프로그램 개발 및 적용
}

\author{
이재인 ${ }^{1}$, 권상현 $^{1}$, 육동원 ${ }^{1}$, 신정택 ${ }^{2}$
}

1 연세대학교

2 동의대학교

[목적] 본 연구 목적은 대학 아이스하키 팀 긍정 심리 개입 프로그램을 개발하고, 현장에 적용하여 그 효과를 검증하 는 것이다.

[방법] 국내 대학 아이스하키 팀 선수 78명을 대상으로 요구분석을 하고, 참여관찰을 실시하여 프로그램 개발을 위한 자 료 수집을 하였다. 전문가 회의를 거쳐 최종 프로그램을 개발하고, $A$ 대학교 아이스하키 팀에 적용하였다. 프로그램 효과 검증은 행복검사 I, 강점 인식, 팀 상호작용 검사지 사전 사후 통계 분석과 경험보고서 및 프로그램 평가지 작성, 선수 심 층면담을 통한 질적 분석도 하였다.

[결과] 첫째, 요구분석을 통한 구성요인 탐색 결과 상호작용, 강점 활용, 긍정 심리 등으로 나타났고 대표적인 요인들을 프 로그램에 반영하였다. 둘째, 프로그램은 현장성이 높고, 신뢰도와 타당성을 확보할 수 있도록 문헌고찰, 참여관찰, 전문 가 회의 등 다양한 방법과 통합 분석에 의거하여 개발하였다. 셋째, 프로그램 목표는 개인 및 팀원 강점 인식 기회 제공, 팀 상호작용과 행복감 증진이다. 넷째, 본 연구를 통해 개발한 프로그램은 대학 아이스하키 팀 선수들에게 행복감, 강점 인식, 팀 상호작용에 있어 통계적으로 유의미한 차이가 나타났고, 긍정심리, 강점 인식 및 활용, 긍정적 상호작용, 팀 응집 력 효과 역시 나타났다.

[결론] 본 연구 결과는 팀 스포츠 현장에서 긍정심리학 활용 가능성을 보여 주며 팀을 위한 긍정 심리 개입 프로그램의 기 초 자료로 제공할 수 있을 것으로 사료된다.

주요어

긍정 심리 개입 프로그램, 대학 아이스하키 팀, 행복, 강점 인식, 팀 상호작용 